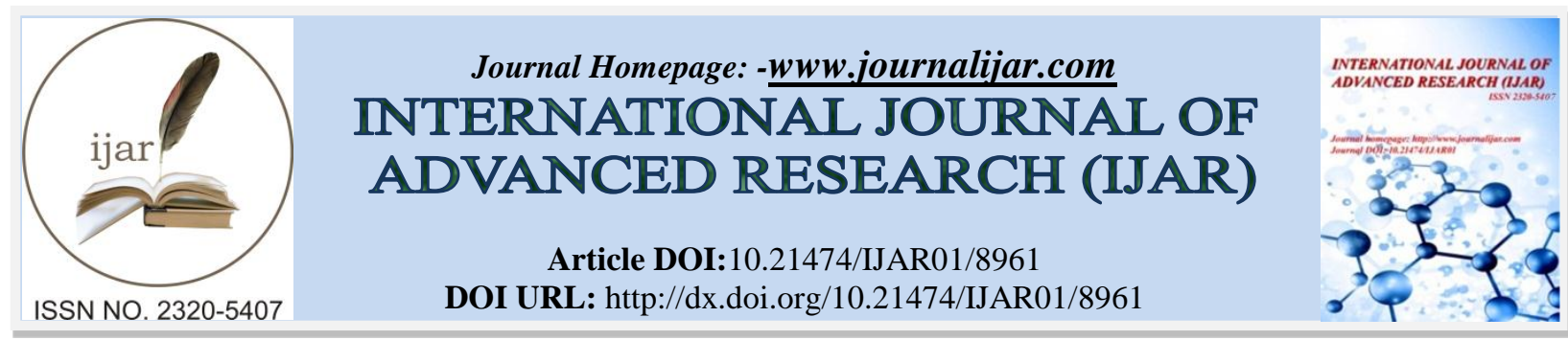

RESEARCH ARTICLE

\title{
PHARMACOGNOSTIC AND PHYTOCHEMICAL EVALUATION OF LEAVES OF CALOTROPIS GIGANTEA.
}

\author{
Pournima A. Shelar ${ }^{1}$, Sucheta Tikole ${ }^{2}$, Poonam Nalawade ${ }^{3}$ And Varsha G. Gharge ${ }^{3}$. \\ 1. Depatment of Pharmacognosy and Phytochemistry, Arvind Gavali College of Pharmacy, Satara, India-415004. \\ 2. Alard college of Pharmacy, Pune, Maharashtra, India. \\ 3. GIPER, Limb, Satara, India-415015.
}

\section{Manuscript Info}

\section{Manuscript History}

Received: 22 February 2019

Final Accepted: 24 March 2019

Published: April 2019

Key words:-

Calotropis gigantea, Physical constants,

Macroscopy, Microscopy,

Phytochemical study.

\begin{abstract}
Arka (Calotropis gigantea) an important drug of Ayurveda is known in this country from the earliest time. It is commonly known as giant milk weed. It is used for several medication purposes in traditional medicinal system. Most recently Calotropis gigantea is scientifically reported for several medicinal properties viz. the flowers were reported to possess analgesic activity, antimicrobial and cytotoxic activity. Leaves and Arial parts of the plant were reported for anti-diarrhoeal activity, antibacterial activity, antioxidant activity. Roots were reported to contain anti-pyretic activity, cytotoxic activity.

The present study is an effort to give detail information regarding macroscopy, microscopy, physical constants, leaf constants, fluorescence analysis and phytochemical screening of leaves extracts of Calotropis gigantea. This study helps in identification of this particular plant species. Also it provides guidelines for identification of plant species.
\end{abstract}

Copy Right, IJAR, 2019,. All rights reserved.

\section{Introduction:-}

The plants posses therapeutic properties or exert Beneficial Pharmacological effects on the animal body are generally designated as "Medicinal Plant". A medicinal plant is any plant which, in one or more of it contains substance that can be used for therapeutic purpose or which is a precursor for synthesis of useful drugs. ${ }^{1}$ Humankind first utilized materials found in environment an empirical basis to cure various ailments. Natural products from plants and animals traditionally have provided the pharmaceutical industry with one of its important sources of lead compounds in search of new drugs and medicines. The search for new pharmacologically active agents from natural resources such as plants, animals and microbes led to discovery of many clinically useful drugs. ${ }^{2,3}$ Since the beginning of civilization, human beings have worshiped plants and such plants are conserved as a genetic resource and used as food, fodder, fibre, fertilizer, fuel, febrifuge and in every other way ${ }^{4}$, Calotropis gigantea is one such plant $^{5}$.

Calotropis belong to Asclepidaceae family. It is also known as Akada, Aak, Mandar, Aakh etc. It has two species procera and gigantean. In ancient ayurvedic medicine the plant Calotropis gigantea is known as "Sweta Arka" and Calotropis procera as "Raktha Arka". Both of them are often similar in their botanical aspects and also have similar pharmacological effects. ${ }^{6}$

Corresponding Author:-Pournima A. Shelar.

Address:-Depatment of Pharmacognosy and Phytochemistry, Arvind Gavali College of Pharmacy, Satara, India-415004. 
The roots and leaves of Calotropis gigantea are used traditionally for treatment of abdominal tumours, boils, skin diseases, wound, insect bites. Calotropis gigantea in small doses are also useful in the treatment of cold, cough, asthma, inflammatory diseases and loss of digestive and analgesic property. ${ }^{7,8}$ Milky sap is used in the treatment of boils, scabies, burns, bruises, cuts, sores, stopping blood, and wound healing; Leaves are used in chest congestion and cardiovascular conditions. The roots and barks of Calotropis gigantea are in use for paralysis, fits, epilepsy, and convulsions in children. Shoot, leaf, roots flowers and latex extracts are reported to have antibacterial and antifungal properties by researchers. ${ }^{9}$ Plants contain many biologically active molecules with different medicinal properties ${ }^{10,11}$. It is popularly known because it produces large quantity of latex and known as milkweed or swallowwort. Latexes are source of various biologically active compounds, including glycosides, tannins and many proteins, among others $^{12,13}$.

\section{Material and method:-}

1. Collection and Authentication of Calotropis gigantea.

2. Determination of physical constants

1. Ash value

2. Total ash

3. Acid insoluble ash

4. Water soluble ash

5. Extractive values

6. Petroleum ether soluble extractive

7. Chloroform soluble extractive

8. Ethanol soluble extractive

9. Water soluble extractive

10. Loss of drying

3. Fluorescence analysis of Leaf powder

4. Study of Macroscopy of Leaf

5. Study of Microscopy of leaf and leaf powder

6 Leaf Constants

1. Stomatal number

2. Stomatal index

3. Vein islet number

4. Veinlet termination number

\section{Collection of Plant material}

The leaves of Calotropis gigantea were collected in the month of June from Satara district. The leaves were authenticated from Department of Botany. Yashawantroa. Chavan. Institute of Science, Satara, Maharashtra, India. Specimen voucher was deposited in the college herbarium for future reference. The fresh leaves were used for study of macroscopic and microscopic characters. Collected Leaves were shade dried and coarsely powdered. This coarse powder was used for determination of extractive values, ash value, LOD and preliminary phytochemical investigation.

\section{Determination of physical constants Determination of Ash Values: ${ }^{14}$ -}

Ash values are helpful in determining the quality and purity of a crude drug, especially in the powdered form. The objective of ashing vegetable drugs is to remove all traces of organic matter, which may otherwise interfere in an analytical determination. On incineration, crude drugs normally leave an ash usually consisting of carbonate, phosphates and silicates of sodium, potassium, calcium and magnesium. The total ash of a crude drug reflects the care taken in its preparation. A higher limit of acid insoluble ash is imposed, especially in cases where silica may be present or when the calcium oxalate content of the drug is very high.

\section{Total ash value:}

Weigh accurately about 2 to $3 \mathrm{gm}$ of the powdered drug in a tarred silica crucible. Incinerate at a temprature not exceeding $450^{\circ} \mathrm{C}$ for $4 \mathrm{hrs}$, until free form carbon, cooled and weighed. Calculate the percentage of ash with reference to air dried drug using following formula,

$\%$ Total ash value $=\underline{\mathrm{Wt}}$. of total ash $\times 100$

Wt. of crude drug taken 


\section{Water soluble ash value:}

The ash was boiled with $25 \mathrm{ml}$ of water, filtered \& collected the insoluble matter on an ashes filter paper, washed with hot water and ignited in a tarred crucible at a temperature not exceeding $450^{\circ} \mathrm{C}$ for $4 \mathrm{hr}$. cooled in desiccators, weighed and subtracted the weight of insoluble matter form the total wt. of ash. The difference in weight represented weight of water soluble ash. Calculated the percentage of water soluble ash with reference to the air dried drug using the following formula-

$\%$ Water soluble ash value $=\mathrm{Wt}$. of total ash $-\mathrm{Wt}$. of water insoluble ash $\mathrm{x} 100$

Wt. of crude drug taken

Acid insoluble ash value:-

Boil the ash for $5 \mathrm{~min}$ with $25 \mathrm{ml}$ of $2 \mathrm{M} \mathrm{HCL}$. Filtered and collected the insoluble matter on an ashless filter paper, washed with hot water \& ignited in a tarred crucible at a temp. Not exceeding $450^{\circ} \mathrm{C}$ for $4 \mathrm{hr}$. cooled in desiccators and weighed. Calculate the percentage of acid insoluble ash with reference to the air dried drug using following formala,

$\%$ Acid insoluble ash value $=\underline{\mathrm{Wt}}$. of acid insoluble ash value $\mathrm{x} 100$

\section{Extractive Values ${ }^{14}$ :}

Wt. of crude drug taken

The extractive values for various solvents of air dried sample were evaluated.

1. Petroleum ether soluble extractive.

2. Chloroform soluble extractive.

3. Methanol soluble extractive.

4. Aqueous soluble extractive.

\section{Petroleum ether soluble extractive value:}

5 gms of air dried powder of Calotropis gigantea, was macerated with $100 \mathrm{ml}$ of pet. Ether in a closed flask, shaking frequently during the first $6 \mathrm{hr}$ and allowed to stand for $18 \mathrm{hr}$ separately. Thereafter, it was filtered rapidly taking precaution against loss of pet. Ether. Evaporated $25 \mathrm{ml}$ of filtrate to dryness in a tarred flat bottom shallow dish dried at $105^{\circ} \mathrm{C}$ and weighed. Percentage petroleum ether soluble extractive was calculated with reference to the air dried drug.

\section{Chloroform soluble extractive value:}

5 gms of air dried powder of Calotropis gigantea, was macerated with $100 \mathrm{ml}$ of chloroform in a closed flask, shaking frequently during the first $6 \mathrm{hr}$ and allowed to stand for $18 \mathrm{hr}$ separately. Thereafter, it was filtered rapidly taking precaution against loss of chloroform. Evaporated $25 \mathrm{ml}$ of filtrate to dryness in a tarred flat bottom shallow dish dried at $105^{\circ} \mathrm{C}$ and weighed. Percentage chloroform soluble extractive was calculated with reference to the air dried drug.

\section{Methanol soluble extractive value:}

$5 \mathrm{gms}$ of air dried powder of Calotropis gigantea, was macerated with $100 \mathrm{ml}$ of methanol in a closed flask, shaking frequently during the first $6 \mathrm{hr}$ and allowed to stand for $18 \mathrm{hr}$ separately Thereafter, it was filtered rapidly taking precaution against loss of methanol. Evaporated $25 \mathrm{ml}$ of filtrate to dryness in a tarred flat bottom shallow dish dried at $105^{\circ} \mathrm{C}$ and weighed. Percentage methanol soluble extractive was calculated with reference to the air dried drug.

\section{Aqueous soluble extractive value:}

5 gms of air dried powder of Calotropis gigantea, was macerated with $50 \mathrm{ml}$ of water at $80^{\circ} \mathrm{C}$ in a closed flask, shaking frequently and allowed to stand for $10 \mathrm{~min}$ so as to cool it and filtered. $5 \mathrm{ml}$ of filtrate was transferred to an evaporating dish, which was $7.5 \mathrm{~cm}$ in diameter, the solvent was evaporated on water bath, allowed to dry for 30 min. finally dried in an oven for $2 \mathrm{hr}$ at $100^{\circ} \mathrm{C}$ and residue was weighed. Percentage of water soluble extractive was calculated with reference to the air dried drug.

\section{Loss of drying ${ }^{15}:-$}

Loss on drying is the loss of mass expressed as per cent w/w. The test for loss on drying determine both water and volatile matter in the crude drug. Moisture is an inevitable component of crude drug, which must be eliminated as far as possible. 
An accurately weighed quantity of about $5 \mathrm{~g}$ of powdered drug was taken in a tarred porcelain dish. The powder was distributed evenly. The porcelain dish kept open in vacuum oven and the sample was dried at temperature $110^{\circ} \mathrm{C}$ for $2 \mathrm{hr}$ until a constant weight was recorded. Then it was cooled in desiccators to R. T., weighed and recorded \% Loss of drying was calculated using the following formula,

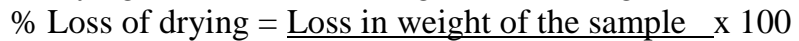

Wt. of crude drug taken

\section{Fluorescence analysis of Leaf powder}

Many drugs shows fluorescence when their powder is exposed to ultraviolet radiation. It is important to observe all materials on reaction with different chemical reagents under U.V. light. The fluorescence characteristics of powdered drug were studied under U.V. light after treating with different chemical reagents is reported. Fluorescence analysis was carried out according to the method of Chase and Pratt ${ }^{16}$ and Kokoski. ${ }^{17}$

\section{Macroscopic Characteristic ${ }^{18,19 .}$}

The macroscopy of fresh leaves were studied according to standard methods.

\section{Microscopic characteristics ${ }^{20}$}

For microscopy hand section of leaf was taken, stained \& mounted following usual micro-techniques.

\section{Leaf Constants ${ }^{21}$ :- \\ Determination of Stomatal number:- \\ Procedure:}

1. Clear the piece of the leaf (middle part) by boiling with chloral hydrate solution or alternatively with chlorinated soda. Peel out upper and lower epidermis separately by means of forceps. Keep it on slide and mount in glycerin water.

2. Arrange a camera lucida and drawing board for making the drawings to scale.

3. Draw a square of $1 \mathrm{~mm}$ by means of stage micrometer.

4. Place the slide with cleared leaf (epidermis) on the stage. Trace the epidermal cell and stomata the area of 1sq.mm. Include the cell if at least half of its area lies within the square.

5. Record the result for each of the ten fields and calculate the average number of stomata per sq. $\mathrm{mm}$

\section{Determination of Stomatal index:-}

\section{Procedure:-}

1. Clear the piece of the leaf (middle part) by boiling with chloral hydrate solution or alternatively with chlorinated soda. Peel out upper and lower epidermis separately by means of forceps. Keep it on slide and mount in glycerin water.

2. Arrange a camera lucida and drawing board for making the drawings to scale.

3. Draw a square of $1 \mathrm{~mm}$ by means of stage micrometer.

4. Place the slide with cleared leaf (epidermis) on the stage. Trace the epidermal cell and stomata.

5. Count the number of stomata, also the number of epidermal cells in each field.

6. Calculate the stomatal index using the formula.

Where,

$$
\text { a. } \quad \mathrm{I}=\frac{S}{E+S} \times 100
$$

\section{$\mathrm{I}=$ Stomatal index}

$\mathrm{S}=$ Number of stomata per unit area.

$\mathrm{E}=$ Number of epidermal cell in the same unit area.

\section{Determination of Vein-islet number:-}

\section{Procedure:-}

1. Clear a piece of the leaf by boiling in chloral hydrate solution for about thirty minutes.

2. Arrange a camera Lucida and drawing board for making drawings to scale.

3. Place stage micrometer on the microscope and using $16 \mathrm{~mm}$ objective, draw a line equivalent to $1 \mathrm{~mm}$ as seen through the microscope.

4. Construct a square on this line.

5. Move the paper so that the square is seen in the eye piece in the center of the field. 
6. Place the slide with the cleared leaf (Epidermis on the stage).

7. Trace off the veins which are included within the square, completing the outlines of those islets which overlap two adjacent sides of the square.

8. Count the number of veins islet in the square millimeter. Where the islets are intersected by the sides of the square, include those on two adjacent sides and include those islet on the other sides.

9. Find the average number of vein islet from the four adjoining Squares, to get the value for one sq.mm.

\section{Determination of vein let termination number:-}

\section{Procedure:-}

1. Clear a piece of the leaf by boiling in chloral hydrate solution for about thirty minutes.

2. Arrange a camera Lucida and drawing board for making drawings to scale.

3. Place stage micrometer on the microscope and using $16 \mathrm{~mm}$ objective, draw a line equivalent to $1 \mathrm{~mm}$ as seen through the microscope.

4. Construct a square on this line.

5. Count the number of terminations present within the square.

6. Find the average number of vein let termination number from the four adjoining squares to get the value for one sq. mm.

\section{Preparation of Extract ${ }^{22 .}$}

The pulverized dried Calotropis gigantea leaves were extracted with methanol by using soxhlet apparatus. The powder of Calotropis gigantea leaves were also macerated with chloroform water. Methanolic and aqueous leaf extracts were filtered \& evaporated to dryness.

\section{Phytochemical Screening 22,23}

Preliminary chemical tests for methanolic and aqueous leaf extracts were carried out according to the standard procedures described by Kokate and Horborne.

\section{Chromatoghraphic Studies ${ }^{24}$}

Thin layer chromatographic studies were carried out for various extracts to confirm the presence of different phytoconstituents in these extract. TLC is a mode of liquid chromatography, in which, the extract is applied as a small spot or band at the origin of thin sorbent layer supported on a glass/ plastic/metal plates. The mobile phase migrates through the stationary phase by capillary action. The separation of solutes takes place due to their differential absorption/partition coefficient with respect to both mobile and stationary phases. Each separated component has same migration time but different migration distance.

The mobile phase consists of a single solvent or a mixture of solvents. Although a number of sorbent like silica gel, cellulose, polyamide, alumina, chemically modified silica gel etc. are used, silica gel (type 60) is most commonly used sorbent. Handmade plates are prepared by using techniques like pouring, dipping, or spraying. Now days, readymade percolated plates are also available. The plates need to be activated at $110^{\circ} \mathrm{C}$ for $1 \mathrm{hr}$. This removes water/ moisture loosely bound to silica gel surface. The retardation factor $\left(\mathrm{R}_{\mathrm{f}}\right)$ is calculated using following formula, $\mathrm{R}_{\mathrm{f}}=$ Distance traveled by sample form base line

Distance traveled by solvent form base line

\section{Thin Layer Chromatography ${ }^{25}$}

Thin layer chromatography is a simple and rapid method carried out using thin layer of absorbent on plates. TLC not only combines the advantage of paper and column chromatography but in certain aspects it is found to be superior to either method. The extract was subjected to thin layer chromatography for the presence of phytoconstituents. In this technique, the silica gel- GF 254 (For TLC) was used as an adsorbent and plates were prepared by spreading technique, then air dried for an overnight and activated for one hour at $110^{\circ} \mathrm{c}$ and used.

\section{Principle-}

In the classification of chromatographic methods, TLC has been included under both absorption and partition chromatography, as various materials of different adsorptive power are used in TLC, the separation of components is not always by adsorptive phenomenon. Separation may result due to adsorption or partition or by both phenomenon depending upon the nature of adsorbents used on plates and solvent system used for development. 


\section{Preparative thin layer chromatography ${ }^{26}$}

A thick layer of silica gel GF-254 was coated on the square shaped plate and activated $110^{\circ}$ for one hour. The broad band ( $2 \mathrm{~mm}$ width) of extracted sample was applied on the plate.

The details of plate as follows-

Plate dimension: $10 \times 20 \mathrm{~cm}$

Adsorbent : silica gel $\mathrm{GF}_{254}$

Activation $\quad: 100 \mathrm{C}$ for one hour

Band parameter: Width $-2 \mathrm{~mm}$, Length- $8 \mathrm{~mm}$

The plate was developed in a saturated chamber having desired solvent system. After developing the plate was dried and if the band gives fluorescence then it can be easily scraped. Otherwise a small portion of the band was sprayed with detecting agent, by taking care to avoid the exposure of remaining plate to spray reagent .Then the band is scraped by measuring the height of sprayed band. The scraped band was then suspended in desired solvent and filtered on what man filter paper no- 1 and washed several times with same solvent. The filtrates were combined and concentrated and reduced to dryness. This procedure was followed for several scrapings. Then the resulted compound was run with original sample to confirm the isolation and subjected to U.V absorption and I.R. spectroscopy studies for identification and partial chacterization.

\section{IR Isolated Compound ${ }^{27,28,29}$}

IR Spetrum was recorded in IR - Spectrometer in 400-4000 frequency in $\mathrm{cm}^{-1}$ for isolated steroids and flavonoids. IR spectrum of compound was carried in KBR pellet and the important absorption can be correlated.

\section{Result:-}

\section{Collection and Authentication of leaves of Calotropis gigantean}

The leaves of Calotropis gigantea were collected and authenticated. These leaves were subjected to further evaluation.

\section{Determination of Physical constants:-}

The Ash Values (Total Ash, Acid insoluble ash, and Water soluble ash), Extractive values (Pet. Ether, Chloroform, Methanol and Water soluble extractives) of leaf powder are given in table-1.

Table No 1:-Physical Constants of Calotropis gigantea Leaves.

\begin{tabular}{|l|c|c|}
\hline Sr no & \multicolumn{1}{|c|}{ Physical constant } & Result \\
\hline A & Ash value (\%w/w) & $15 \%$ \\
& $\bullet \quad$ Total Ash & $1.5 \%$ \\
& $\bullet \quad$ Acid Insoluble Ash & $3 \%$ \\
\hline B & Extractive Values (\% w/w) & 0.4 \\
& $\bullet \quad$ Petroleum ether soluble extractive & 1.6 \\
& $\bullet \quad$ Chloroform soluble extractive & 7 \\
& $\bullet \quad$ Methanol soluble extractive & 19.2 \\
\hline C & Aqueous soluble extractive & $15.8 \%$ \\
\hline
\end{tabular}

Fluorescence analysis of leaf powder:

Table No 2:-Fluorescence analysis of Calotropis gigantea Leaves powder.

\begin{tabular}{|l|c|c|}
\hline \multirow{2}{*}{\multicolumn{1}{|c|}{ Reagent }} & \multicolumn{2}{c|}{ Fluorescence observed } \\
\cline { 2 - 3 } & At $254 \mathrm{~nm}$ & At $366 \mathrm{~nm}$ \\
\hline Powder $+1 \mathrm{~N} \mathrm{NaOH}$ in methanol & Violet & Faint green \\
\hline Powder $+1 \mathrm{~N} \mathrm{NaOH}+$ water & Violet & Faint green \\
\hline Powder $+50 \% \mathrm{HCL}$ & Faint violet & Dark green \\
\hline Powder $+50 \% \mathrm{H}_{2} \mathrm{SO}_{4}$ & Faint violet & Faint green \\
\hline Powder $+50 \% \mathrm{HNO}_{3}$ & Violet & Faint green \\
\hline
\end{tabular}




\begin{tabular}{|l|c|c|}
\hline Powder +Pet. Ether & Violet & Dark green \\
\hline Powder + Chloroform+ Picric acid. & Faint violet & Dark green \\
\hline Powder+ Methanol & Violet & Faint green \\
\hline Powder+ $\left(\mathrm{HNO}_{3}+\mathrm{NH}_{3}\right)$ & Violet & Dark green \\
\hline
\end{tabular}

\section{Macroscopic Characteristic of Leaf.}

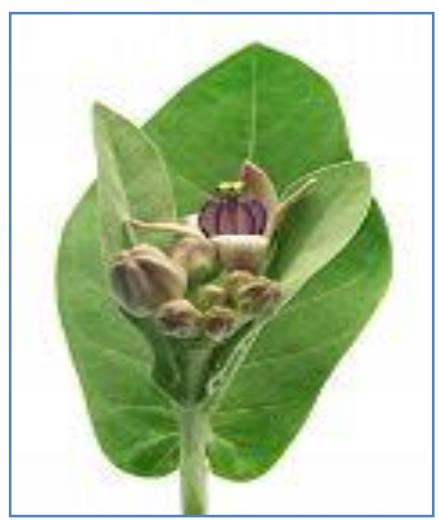

Figure No 1:- Macroscopy of Calotropis gigantea leaf

Simple, opposite, sub-sessile, slightly thick, fleshy, $10-15 \mathrm{~cm}$ long and 4.5 to $6.5 \mathrm{~cm}$ broad, broadly obovate or obovate oblong, slightly cordate and auricled at base with tuff of short simple hairs on the upper side near place of the attachment to the petiole. The tender leaves are covered with ashy gray pubescence. Mature leaves are nearly smooth or even glabrous and pale green.

\section{Microscopic Characteristics of Calotropis gigantea Leaf.}

\section{Lamina:}

Dorsiventral nature

\section{Midrib:}

\section{Upper epidermis and Lower epidermis:}

Transverse sections through the midrib showed an upper and lower, single- layered epidermis that was externally covered with a thick, striated cuticle, a few epidermal cells on both lower and upper surfaces, parenchymatous cells that were thin-walled and isodiametric to circular. Intracellular spaces were present in ground tissue. The upper and lower epidermis was covered externally with a thick, striated cuticles. Lower epidermis is similar to upper epidermis.

\section{Collenchyma:}

Collenchyma present below upper and above lower epidermis, containing groups of cellulosic cells. These are thick walled cellulosic cells, present above the lower epidermis.

\section{Vascular bundle:}

Two vascular bundles are arranged in ring and composed of bicollateral and open vascular bundles. The xylem consists mostly of vessels and tracheids.

Xylem: Xylem is lignified, Phloem: Phloem is Non-lignified.

\section{Stomata:}

Paracytic stomata are present.

\section{Mesophyll:}

The mesophyll was seen to be differentiated into a palisade and spongy tissues, 


\section{Palisade:}

Below the upper epidermis were three rows of elongated, closely arranged, palisade parenchyma are present.

\section{Spongy parenchyma:}

Spongy parenchyma tissues were almost compact cells, radially elongated,covering only lamina portion. 6-8 layers are present.

\section{Midrib}

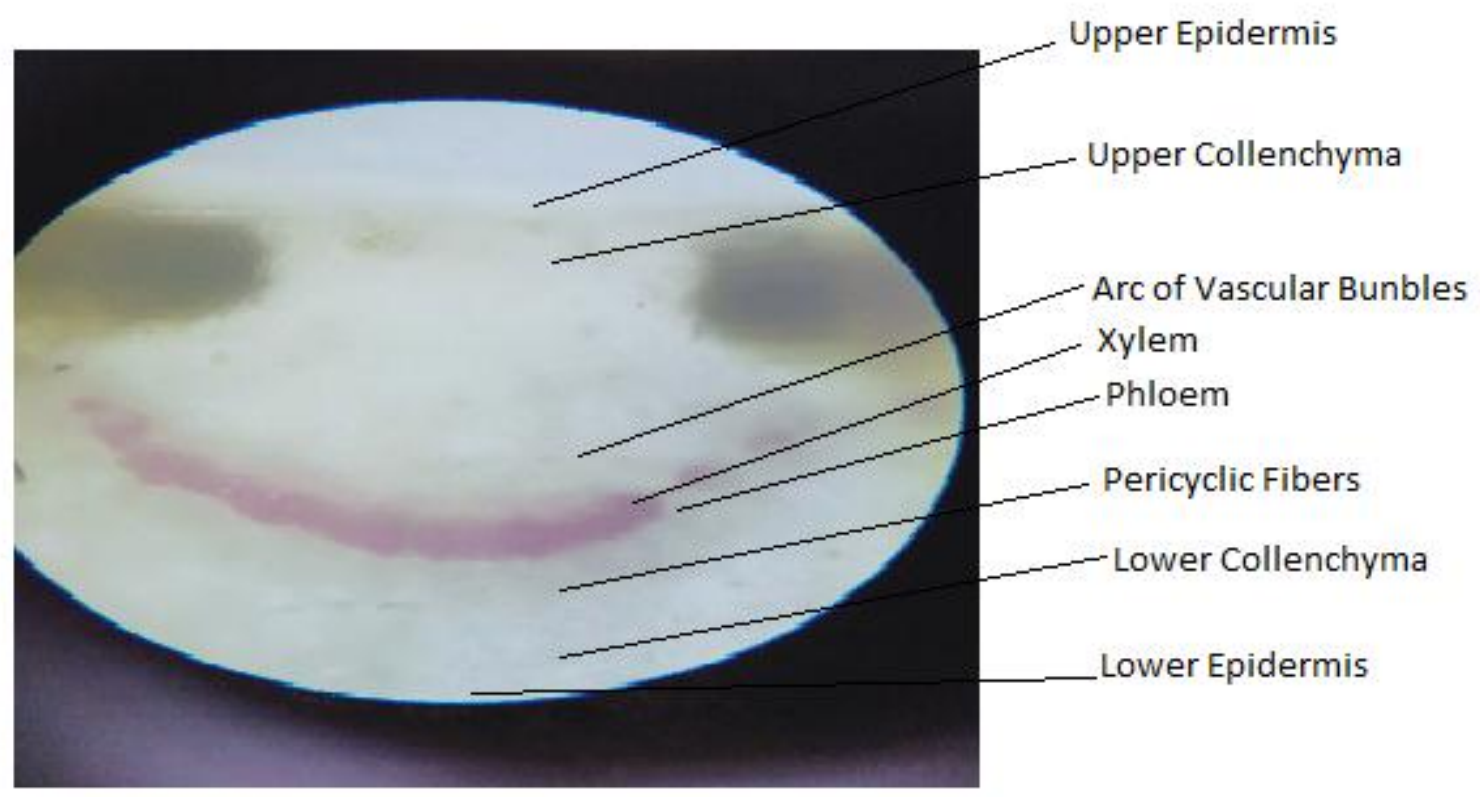

Figure No 2:- Microscopy of Midrib of Calotropis gigantea leaf.

\section{Lamina}

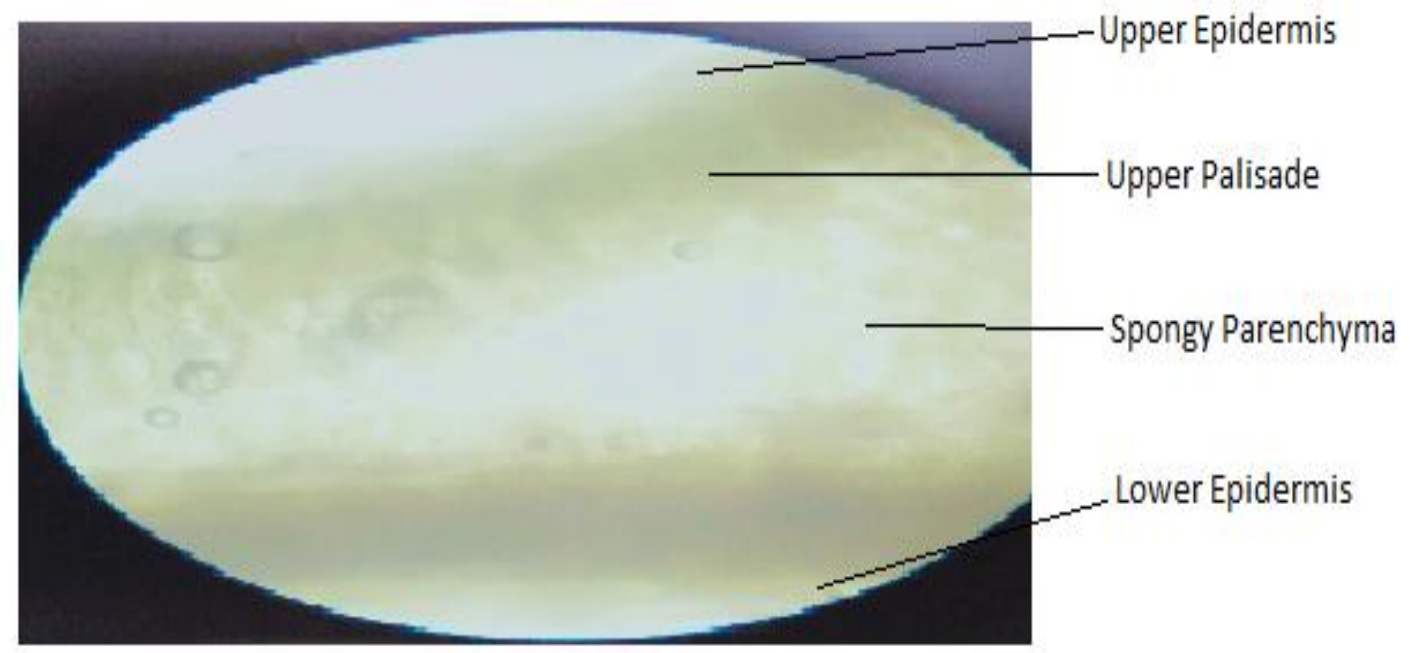

Figure No 3:- Microscopy of Lamina of Calotropis gigantea leaf. 


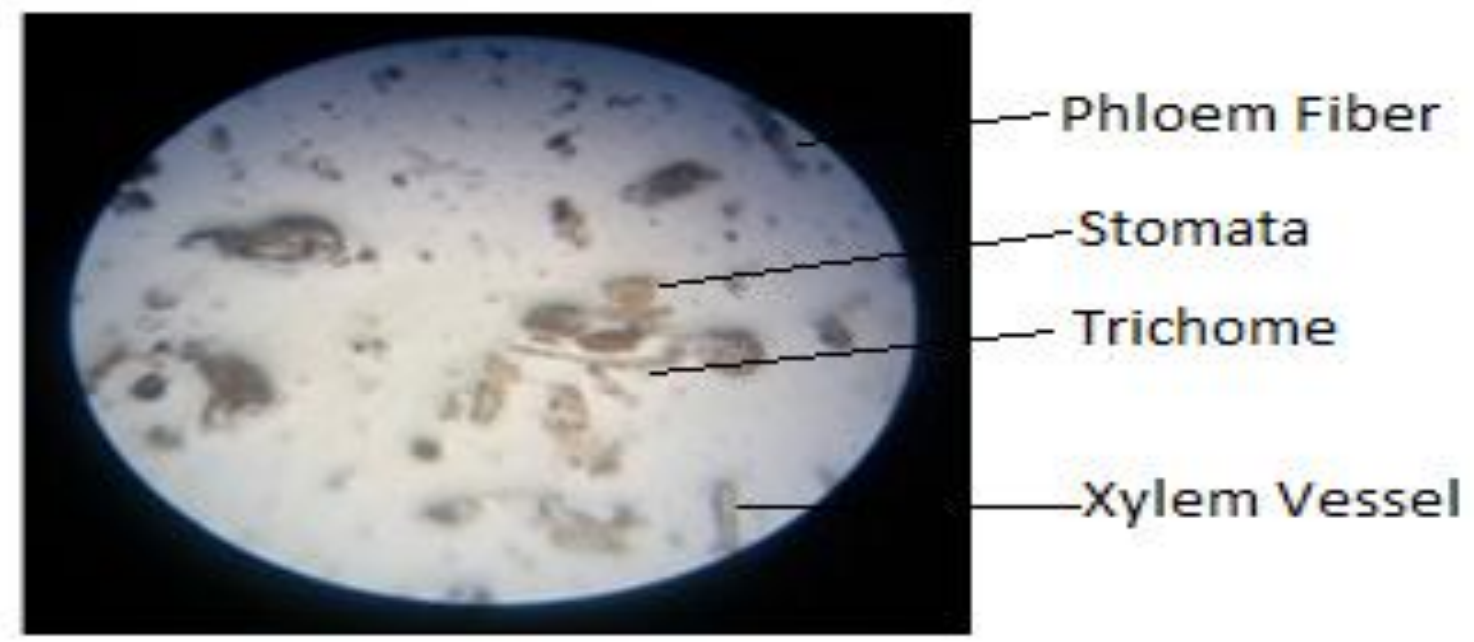

Figure No 4:- Powder microscopy of Calotropis gigantea leaf.

\section{Leaf Constants:-}

The leaf constants like Stomatal number, Stomatal index, vein Islet number, Veinlet terminationnumber were mentioned below:-

\section{Observations:-}

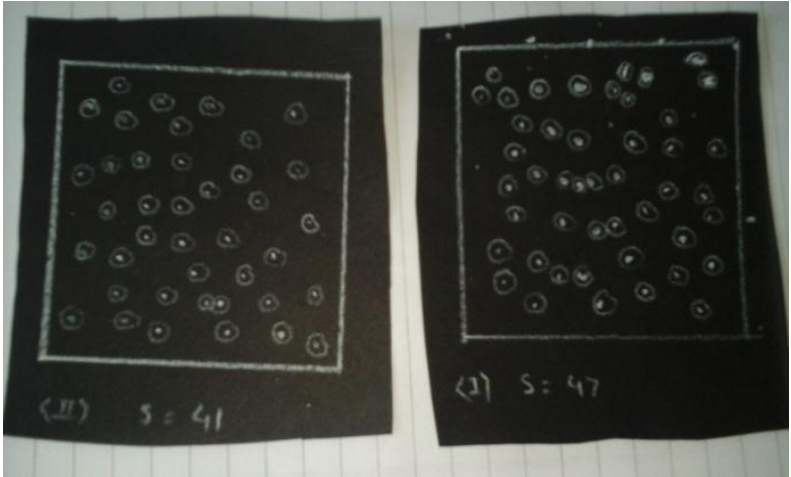

Stomatal number

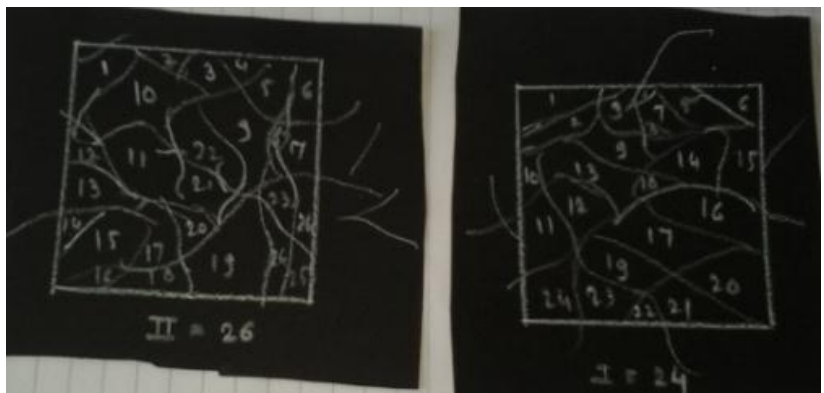

Vein islet number

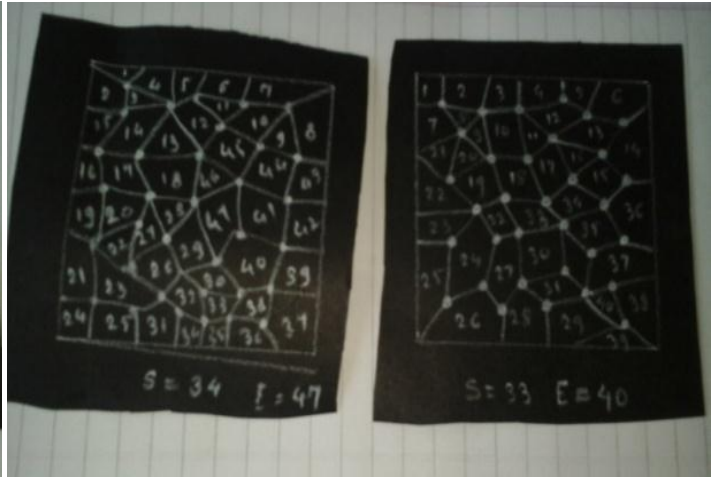

Stomatal index

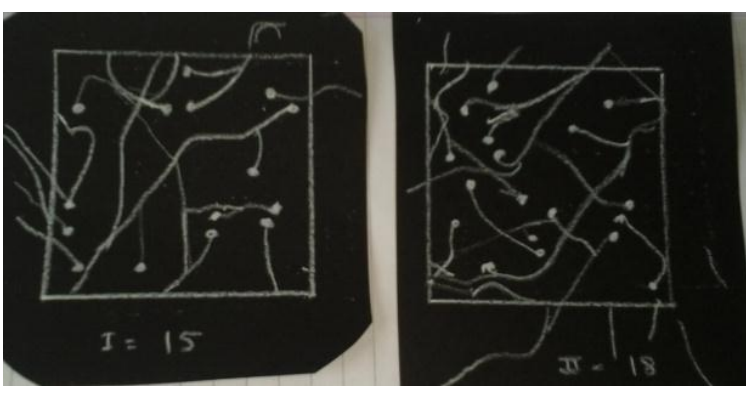

Veinlet termination number

Figure No 5:- Leaf constants of Calotropis gigantea leaf.

Table No. 3:-Leaf constants of Calotropis gigantea Leaves.

\begin{tabular}{|c|l|c|}
\hline Sr. No. & \multicolumn{1}{|c|}{ Leaf Constant } & Result \\
\hline A & Stomatal number & $44 / \mathrm{sq} . \mathrm{mm}$ \\
\hline
\end{tabular}




\begin{tabular}{|c|l|c|}
\hline B & Stomatal index & $43 / \mathrm{sq} \mathrm{mm}$ \\
\hline C & Vein- islet number & $25 / \mathrm{sq} \mathrm{mm}$ \\
\hline D & Veinlet- termination number & $16.5 / \mathrm{sq} . \mathrm{mm}$ \\
\hline
\end{tabular}

7. Extraction:-

Table No 4:-Obsrervation table of Nature, Colour, Yield of Colotropis gigantea extracts.

\begin{tabular}{|c|l|c|c|c|}
\hline Sr no & \multicolumn{1}{|c|}{ Extract } & Nature of extract & Colour & Weight \\
\hline 1 & Methanolic & Solid & Greenish brown & 7 \\
\hline 2 & Aqueous & Semi solid & Greenish brown & 19.2 \\
\hline
\end{tabular}

8. Phytochemical screening:-

Table No 5:-Qualitative chemical investigation of Calotropis gigantea Extracts

\begin{tabular}{|l|l|c|c|}
\hline Sr no & \multicolumn{1}{|c|}{ Name of the test } & Methanolic extract & Aqueous extract \\
\hline 1 & Test for sterols & + & + \\
\hline 2 & Test for Triterpenoids & + & + \\
\hline 3 & Test for glycoside & + & + \\
\hline 4 & Test for carbohydrate & - & - \\
\hline 5 & Test for alkaloids & + & - \\
\hline 6 & Test for flavonoids & + & - \\
\hline 7 & Test for tannins & - & - \\
\hline 8 & Test for proteins & - & - \\
\hline 9 & Test for amino acid & + & + \\
\hline 10 & Test for volatile oil & + & + \\
\hline 11 & Test for saponin & & \\
\hline
\end{tabular}

Thin layer chromatography of Calotropis gigantea.

Stationary phase : Silica gel GF-254

Mobile phase $\quad$ : Ethyl acetate: formic acid: glacial acetic acid: water.

Proportion : $\quad$ : $100: 11: 11: 26)$

Detection : UV-366

Solvent front $\quad: 5.4$

Spot detection $\quad: 2.7$

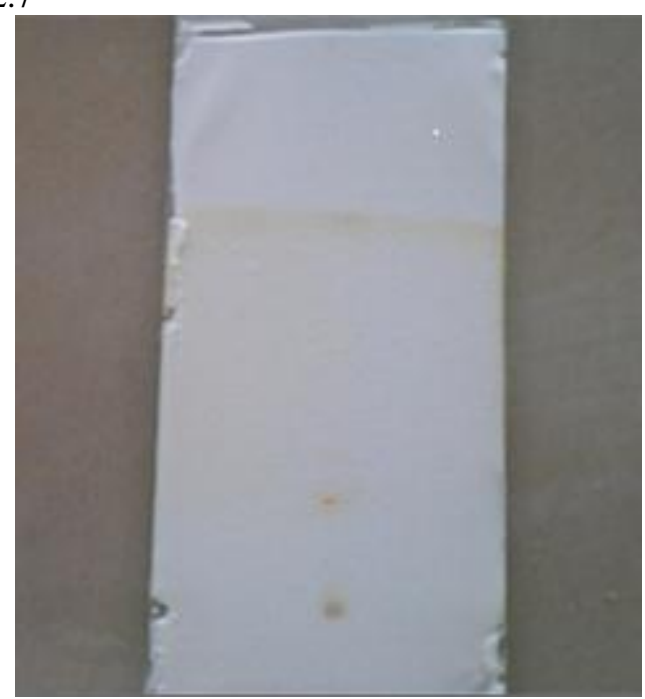

Figure no 6:-TLC of Methanolic extract of Calotropis gigantea.

Table No. 6:-TLC of Methanolic extract of Calotropis gigantea.

\begin{tabular}{|c|c|c|}
\hline Sr & Mobile phase & $\mathbf{R}_{\mathrm{f}}$ Value \\
\hline
\end{tabular}




\begin{tabular}{|l|l|c|}
\hline no. & \multicolumn{1}{|c|}{} \\
\hline 1 & Ethyl acetate:formic acid:glacial acetic acid: water. & 0.5 \\
\hline
\end{tabular}

\section{IR of Isolated Compound}

Spetrum was recorded in IR - Spectrometer in 400-4000 frequency in $\mathrm{cm}^{-1}$ for isolated compound.

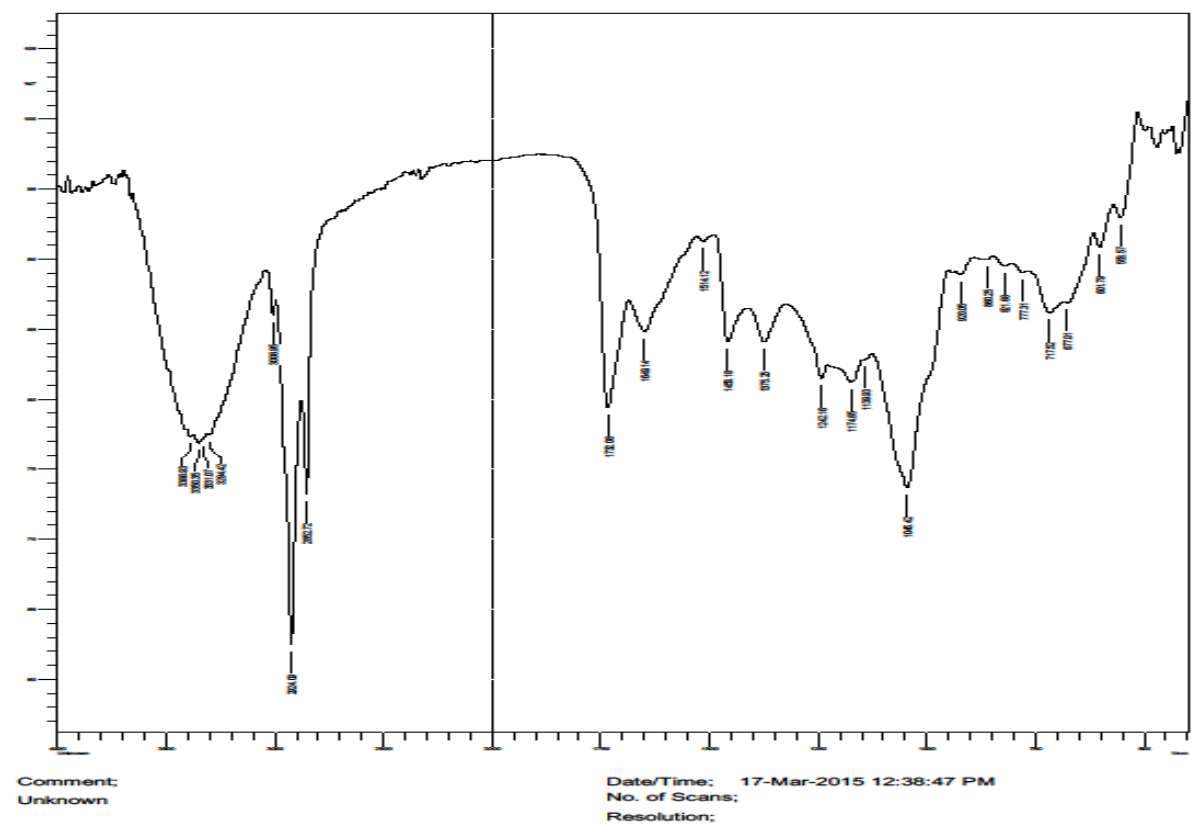

Figure no. 7:-IR Spectrum of isolated compound from Methanolic extract.

Table No. 7:-Spectral analysis of isolated compound of Methanolic extract.

\begin{tabular}{|l|l|l|}
\hline $\begin{array}{l}\text { Spectral peak (cm- } \\
\text { 1) }\end{array}$ & \multicolumn{1}{|c|}{ Molecular Nature } & \multicolumn{1}{|c|}{ Standard value } \\
\hline 3388.93 & O-H Streching (carboxylic acid) & $3400-3200$ \\
\hline 3350.35 & O-H Streching ( H Bonded) & $3400-3200$ \\
\hline 3331.07 & O-H Streching & $3400-3200$ \\
\hline 3294.42 & O-H Streching & $3400-3200$ \\
\hline 2924.09 & C-H stretch (Alkanes) & $3000-2850$ \\
\hline 2852.72 & CHO Stretch ( Aldehyde) & $3000-2850$ \\
\hline 1732.08 & C=O Bending (Ester) & $1750-1730$ \\
\hline 1045.42 & C-O Bending ( Alcohol, ester, carboxylic acid) & $1300-1000$ \\
\hline 717.52 & C- H Aromatic (Plane bending) & $900-690$ \\
\hline
\end{tabular}

\section{Discussion:-}

1. The leaves were collected from Satara district, Maharashtra region and authenticated. The leaves were subjected for Pharmacognostic investigation which includes determination of physical constants such as ash value, extractive values and loss on drying, fluorescence analysis.

2. Macroscopic and microscopic characteristics of the leaf were studied. The microscopic study shows that it contains midrib and lamina portion. The lamina shows upper and lower epidermis, spongy parenchyma, palisade cell layer while midrib portion shows upper and lower epidermis, collenchyma, Arc of vascular bundle, etc., Powder characteristics shows presence of paracytic stomata and covering trichomes.

3. The leaf constants like Stomatal number, Stomatal index, vein Islet number, Veinlet termination number were determined. 
4. The leaves of plant were subjected to extraction by using methanol and water and these extracts were subjected to phytochemical investigation.

5. Phytochemical investigation of extracts of Calotropis gigantea shows that aqueous extract contains sterols, glycosides, carbohydrates, triterpenoids, tannins. While methanolic extract shows presence of sterols, flavonoids, glycosides, carbohydrate, triterpenoids and tannins.

6. Chromatographic study of Methanolic extract was carried out. Where Thin layer chromatography was carried out by using mobile phase Ethyl acetate:formic acid:glacial acetic acid: water (100:11:11:26) which shows $\mathrm{R}_{\mathrm{f}}$ value 0.5 for flavonoids.

7. For these isolated compounds infra red spectroscopy was carried out which shows that methanolic extract contains aromatic ring, hydroxyl group, esters, alkanes, aldehydes, carboxylic and alcoholic groups, etc.

\section{Conclusion:-}

Calotropis gigantea is widely found in India during any season. As there is less information available on pharmacognostical work on leaves hence morphological study, microscopical studies, physico-chemical parameters and chemical tests performed will guide in the proper identification of the plant species as well as help in authentication of the purity of the plant. All these parameters also help to build up a suitable plant profile.

\section{References:-}

1. Pramila kori, Prerana alawa., Antimicrobial activity and phytochemical analysis of Calotropis gigantea root, latex extracts. IOSR Journal Of Pharmacy 2014; 4 (6) : 07-11.

2. Chitme HR, Chandra R, Kaushik S, Studies on anti-diarrhoeal activity of Calotropis gigantea R.Br. In experimental animals. J Pharm Pharmaceut Sci 2004; 7(1):70-75.

3. Anurag A, Namrata S, Pharmacological aspects of Calotropis gigantea on various health problems: A review. IJAPR 2011; 2(12): 613-620.

4. Sureshkumar P, Chezhian A, Senthil Raja P and Sathiyapriya J; Computational selections of terpenes present in the plant Calotropis gigantea as mosquito larvicide's by blocking the sterol carrying protein, Bangladesh $\mathrm{J}$ Pharmacol, 2012, 7: 1-5.

5. Calotropis gigantea, R. Br., Bulletin of Miscellaneous Information, Royal Gardens, Kew, 1900;157/168: 8 - 12.

6. P. Suresh Kumar. Review on a potential herb Calotropis gigantea (L.) R. Br. Scholars Academic Journal of Pharmacy, , 2013; 2(2):135-143

7. Kartikar, K. R. And B.D. Basu, Indian Medicinal Plants,Edn 2nd, Allahabad, India. 1994, Vol. 3, $1606-1609$.

8. Chitme, H.R., R. Chandra and S. Kaushik, Evalution of antipyretic activity of Calotropis gigantea (Asclepiadaceae) in experimental animals. Phytothrapy Research, 2005, 19 (5):454-6.

9. Suresh Babu AR and Karki SS, Wound Healing Activity of Calotropis gigantea leaves in Albino Wistar Rats. International Journal of Pharmacy. 2012,. 2(1): 195-199

10. Newman DJ, Cragg GM, Snader KM., Natural products as sources of new drugs over the period 1981-2002. Journal of Natural Product 2003, 66(7): 1022-1037.

11. Butler M., Natural products as new drugs. Journal of Natural Product 2004; 67(12): 2141-2153.

12. Dubey VK, Jagannadham MV (2003) Procerain, a stable cysteine protease from the latex of Calotropis procera. Phytochemistry 62(7): 1057-1071.

13. Chandrabhan S, Sumint ST (2011) Antibacterial efficacy and phytochemical analysis of organic solvent extracts of Calotropis gigantean. J Chem Pharm Res 3(6): 330-336

14. Kokate CK., Practical Pharmacognosy; Vallabh Prakashan. $5^{\text {th }}$ Edition.2014, 124, 125.

15. Indian Pharmacopoeia, Government of India, Ministry of Health and Family Welfare, Controller of Publication, $4^{\text {th }}$ ed, New Delhi, 1996. 4(II), A53-A54.

16. Chase, C.R and Pratt, R.S., Fluorescence of Powdered Vegetable drugs with particular reference to Development of a System of Identification. J. Am. Pharmacol. Assoc 1949:38, 32.

17. Kokoski J I, Kokoski R, Salma F J; Fluorescence of powdered vegetables drugs under ultraviolet radiation. J. Am. Pharm.Ass.1958; 47:715-717.

18. Mukherjee PK, Quality control of herbal drugs, Bussiness Horizon's, Pharmaceutical publisher, New Delhi, 2002, 138-141.

19. Evans WC, Trease and evans, Pharmacognosy, W.B. Saunders, Edinburgh London, New York Philadelphia, $15^{\text {th }}$ Edition, Pg. No.519-520, 545-547.

20. Johansen DA, Plant microtechniques, McGraw-hill Book Company, New York \& London, $1^{\text {st }}$ Ed $^{\text {n }} 1940,182-$ 203. 
21. Khandelwal K. R., Practical Pharmacognosy Techniques and Experimental Nirali prakashan $18^{\text {th }}$ Ed. 2007; page no. 146, 147, 148.

22. Harborne, J.B., Methods of extraction and isolation. In: Phytochemical methods, $3^{\text {rd }}$ ed, Chapman and Hall, London 1998, 60-66.

23. Kokate, C.K., Practical Pharmacognosy, ${ }^{\text {st }}$ Ed, Vallabh Prakashan, New Delhi 1986, 1, 15-30.

24. Chatwal GR, Anand SK. Instrumental methods of chemical analysis, $7^{\text {th }}$ ed., Himalaya Publishing House. 1992; 588-598.

25. .Ergon Stahl. Thin Layer Chromatography, A Laboratory Hand Book, $2^{\text {nd }}$ ed., New York 1990; 52-59.

26. Harborne JB. Methods of extraction and isolation, Chapman \& Hall, $2^{\text {nd }}$ ed., London. 1988; 28-33.

27. William Kemp. Organic Spectroscopy, $3^{\text {rd }}$ ed. 1991; 58-269.

28. Chatwal G, Spectroscopy (Atomic ad Molecular), Himalaya Publishing House, $5^{\text {th }}$ ed. 2001; 2.29-2.234.

29. Sharma BK, Instrumental method of chemical analysis, $22^{\text {nd }}$ ed., Goel Publishing House, Merrut. 2002; 180224. 